\title{
MURDELIIGENDUSED XVI-XVIII SAJANDI EESTI KIRJALIKES ALLIKATES
}

\section{SIIM ANTSO}

\begin{abstract}
Annotatsioon. Artikkel käsitleb eesti keele geograafilise varieerumise uurimist ja esitlemist vanemates kirjalikes allikates. Artiklis analüüsitakse XVI-XVIII sajandi tekste sotsio- ja koloniaallingvistilisest ning ajaloolise tajudialektoloogia vaatenurgast. Artikli eesmärk on esitada sidus murdeuurimise teaduslugu, milles on näidatud tekstide ja autorite omavahelised seosed ning nende mõju järgnevatele teadustöödele. Analüüsitakse vanimat säilinud eestikeelset teksti, Wanradti-Koelli katekismust, mitmeid selle perioodi grammatikaid (nt Gösekeni ja Hupeli) ning kroonikaid (nt Hiärne ja Jannau). Analüüsist selgub, et vanemates kirjalikes allikates liigitati eesti murdeid toonaste haldusüksuste põhjal. Põhilised mainitud murdeüksused olid makonnad, ent mitmed autorid tõdesid, et igal kihelkonnal võib olla omalaadne murre. Väga olulised üksused nendes liigendustes olid ka suured keskused, nagu Tartu, Tallinn, Pärnu, Viljandi ja Narva, mille (linna-) keeli eristati maakondade keeltest. Eesti- ja Liivimaa ajalootekstides liigitati eesti keelt sageli soome keele murdeks, liivi keelt jällegi eesti keele murdeks.
\end{abstract}

Võtmesõnad: eesti keel, eesti murded, sotsiolingvistika, koloniaallingvistika, ajalooline tajudialektoloogia

\section{Sissejuhatus}

Eestimaa pinnal räägitud ja räägitavaid keelekujusid on nimetatud ja liigendatud mitmeti, näiteks murrakuks, murdeks, kirja- või ühiskeeleks. Pole teada, kuidas muistsed Eesti elanikud, st (hilisemad) eestlased oma keelt nimetasid ja liigendasid. Kõik kirjalikud allikad varase eesti keele arengu kohta pärinevad baltisaksa pastoritelt ja üldteaduslike huvidega haritlastelt. Eesti keele lugu ja loomet võib seega vaadelda koloniaallingvistika raamistuses, kus keelt uurivad ja korraldavad teise emakeele ja sotsiaalse staatusega inimesed.

Sellel, kuidas üht keelekuju kategoriseeritakse, on kahtlemata väga suur ideoloogiline ja keelepoliitiline (st keelekujusid eelistav) mõju kogu 
keelekeskkonnale. Sellise keeleloome levinum näide on rahvuskeelte (sh normikeelte) kujunemine ja kujundamine (nt kas või põhjaeestilise kirjakeele kujundamine rahvuskeeleks). Einar Haugen on kirjeldanud rahvuskeelte loomist suure hulga valikutena: a) mis piirkonna keel võetakse aluseks, b) mis vormid ühtlustatakse ja kinnitatakse korrektseteks, c) mis funktsioone uuele keelele ühiskonnas antakse ning d) mida tehakse, et inimesed selle keele omaks võtaksid ja teisi keeli või keelekujusid (nt murdeid) argisemates olukordades kasutaksid (Haugen 1966: 933). Haugen juhib samas tähelepanu sellele, et keeli kategoriseerivates terminites pole alati ühtsust olnud. Näiteks murde ja keele puhul võib ainult ühel või ka mõlemal olla kirjalik kuju. (Haugen 1966: 923-924) Erinevused murde ja keele kategooria vahel on hierarhilis-sõltuvuslikud ning funktsionaalsed ehk üks on teise alammõiste ja ühel on ühiskonnas täita rohkem funktsioone kui teisel (ibid.: 926). Selleks, et oleksid olemas murded, peab esmalt olema keel: teisisõnu, ilma keeleta on murde mõiste sisutühi (Auer 2005: 2).

Eesti keele ja selle uurimise varast perioodi on varem käsitletud peamiselt kirjakeele aspektist (Habicht 2003; Ross 2009, 2016). Eesti keele varieerumise liigendamist on käsitletud vähem: lühikese varase murdeuurimise ülevaate leiab näiteks Arnold Kaselt (1984). Seni pole aga põhjalikult analüüsitud eesti murrete varast liigendamist ja seda mõjutanud tegureid. Küll aga on uuritud, kas ja kuidas ühiskonda muutnud sündmused, Lääne-Euroopa mõttelugu ning autorite allika- ja teemavalik on jätnud jälje baltisaksa ajalookirjutusse (vt Laidla 2007). Seda laadi teadusloo süvauurimine annab aimu teadustraditsiooni kujunemisest ning sellest, kuidas on teksti- ja mõttejärgnevus hilisemaid töid mõjutanud.

Selle artikli huvikeskmes on uurida, kuidas on teise emakeele ja sotsiaalse-kultuurilise taustaga inimesed paikkondlikult eriilmelisi keelekujusid nimetanud, kirjeldanud ja kategoriseerinud. Analüüs põhineb autorite endi metakommentaaridel, mitte esitatud keelenäidetel. Mõistagi võib oletada autori esitatud keelenäidete põhjal, mis piirkondlike keelekujudega ta kursis oli, ent olulisem on siin see, kuidas on ta neid näiteid süstematiseerinud ja liigendanud. Artikli eesmärk on käsitleda eesti keele murdelist liigendamist ja dialektoloogia n-ö teaduseelset arengut XVIXVIII sajandil, mille järel hakkas keeleteadus välja kujunema rahvusideede leviku, rahvuslike seltside ja ajakirja Beiträge zur genauern Kenntniss der esthnischen Sprache (1813-1932) toel. 


\section{Murdeliigenduste sotsiolingvistilise analüüsimise meetodid}

Eesti keelekujude varieerumise varase, st rahvusloome-eelse kujutamise analüüsimisel on oluline arvesse võtta kolme iseloomulikku punkti. Esiteks, eesti murrete kirjeldamise algus on koloniaalne. Teiseks, murde kirjapanijad ei olnud erialalt keeleteadlased. Tollaste pastorite, haritlaste ja õpetlaste uurimishuvi ja -motivatsioon ei piirdunud üksnes keelega ning ajastuomaselt ei saanudki neil olla süstemaatilist keeleteaduslikku (metodoloogilist) väljaõpet. Kolmandaks tuleks senisest enam tähelepanu pöörata inimtekkeliste ja looduslike tõkete mõjule murrete liigendamisel. Nende teemade teoreetilisi käsitlusi on kirjeldatud selles peatükis.

\subsection{Koloniaallingvistika}

Koloniaallingvistika on mitmetahuline kodustamisprotsess, milles allutatud rahvaste keelt, uskumusi ja kombeid mõjutab valitseva võimu kultuur. Selle tulemusena saab võõrast oma ning ebamäärasest konkreetne (ja sageli lihtnegi). (Errington 2001: 21) Ümberasujad säilitasid oma identiteedi ja sidemed emamaaga, olles ise aga parema elujärje otsinguil. Seega motiveeris ümberasujaid (muu hulgas) pettumus, olgu selleks siis majanduslik, religioosne või poliitiline vajakajäämine. (Young 2001: 20) Koduse, kuid samas parema sotsiaalse korra ülesehitamise juurde kuulus allutatud rahva veenmine, et neidki on tuldud päästma (Fanon 2004: 149). Baltisaksa koloniaaldiskursus polnud ainulaadne sellele regioonile, vaid kujutas endast saksaliku ja laiemalt euroopaliku käsitluse teostust (Kaljundi, Plath 2017: 5). Rahvuslik ja baltisaksa koloniaaldiskursus on põimunud samade teemade ja sündmuste kaudu. (ibid.: 4)

Eesti keele uurimise koloniaalsest algupärast on kirjutanud Kristiina Ross (2009: 554), nimetades seda ka saksa kultuuri hüljatud osaks. Kolonialism väljendub mitmel viisil, olles näiteks õpetlik-ettekirjutav, uuriv-kirjeldav või mõlema diskursuse kooslus. Olenevalt eeldatavast lugejaskonnast ja teose eesmärgist võib keelt kirjeldavatel või korrastavatel teostel olla suurem eesmärk kui praktiline huvi korrastada võõrast keelt paremaks suhtlemiseks kohalikega. Peale oma emakeele on ideaalne keelemudel olnud ladina keel: „Suure osa Euroopa rahvuslike filoloogiate teke või eellugu on olnud välisvaateline, kuivõrd kuni XVII sajandi lõpuni oli kõigi uuritavate nähtuste kirjelduskeeleks enamasti ladina keel.“ (Ross 2016: 652) 
Eesti kontekstis on see olukord olnud keerulisemgi, arvestades pidevalt vahetuvaid võõrvõime ja nendega kaasnevaid halduskordi. Kohalik keel jäi selles keskkonnas võõrvõimu emakeele suhtes alati alamaks (Keevallik, Pajusalu 1995: 13). Maa ümberjagamistega paisati segi keeleala: uute halduspiiride kehtestamisel ja talupoegade liikumise piiramisel arvestati harva keelelähedusega (ibid.: 18).

\subsection{Ajalooline tajudialektoloogia}

Hinnanguid ja arvamusi keele geograafilise varieerumise kohta on uuritud tajudialektoloogia vallas (ingl perceptual dialectology). On arvatud, et sotsiolingvistika seesmisest arengust mõjutatud uuemad lähenemised, nagu tajudialektoloogia, on keele varieerumise piirkonda analüüsinud oluliselt suurema tähelepanuga kui varasemad lähenemised (Blommaert 2013). 1980. aastatel populaarsust kogunud tajudialektoloogia eesmärk on uurida tavakõnelejate (st erialase hariduseta kõnelejate) (eel)arvamusi keele varieerumise kohta. Tajudialektoloogia on sünkroonne murdeteadus, mis uurib murdekõnelejaid ja neilt saadud vahetut materjali, kuid ei keskendu mitte kõneloomele (st sellele, kuidas räägitakse), vaid sellele, kuidas tavakõnelejad tajuvad ja väljendavad murde varieerumist. Eesmärk on võrrelda keeleteadlaste ja tavakõnelejate arusaamu. Need kaks ei vastandu, vaid üks täiendab teist. (Preston 1999: xxv)

Kuna traditsiooniline dialektoloogia on keskendunud murdematerjali talletamisele, mitte niivõrd tavakõnelejate arvamuste kogumisele, on tajudialektoloogia jäänud materjali vähesuse tõttu suuresti sünkroonseks. Võimalik lahendus ongi uurida kirjanike, ajaloolaste ja teiste töid, milles on dokumenteeritud või avaldatud arvamust keele ja murrete kohta. Just sellist vaadet teadusloole on rakendanud Alexander Maxwell (2006: 162), nimetades oma uurimusi ajalooliseks tajudialektoloogiaks (ingl historical perceptual dialectology). Paraku ei saa ajaloolise tajudialektoloogia raamistikus rakendada tajudialektoloogia eriomaseid katselisi meetodeid (nt kujutluskaarte). Seetõttu tuleb toetuda kõikidele relevantsetele ja kättesaadavatele allikatele: ajaloolistele murdekaartidele, murdekirjeldustele, grammatikatele ja kirja pandud pärimusele. Seda tuleb teha ajastuomase tundlikkusega, ent allikakriitiliselt.

Ajalooliste allikate autorid olid enamasti haritumad, paremal järjel, kõrgemal positsioonil ja mõjukamatel ametikohtadel. Siiski ei ole olnud 
keelt käsitlevate kirjutiste autorid enamasti erialalt keeleteadlased, vaid vaimulikud, arstid või mõne muu eriala spetsialistid, mittekeeleteadlased, kellel oli keele-, kultuuriloo- või ajaloohuvi. Kahtlemata ei moodusta mittekeeleteadlased sidusat ja diskreetset kategooriat, tegemist ei ole püsiva staatusega, vaid pigem on tegu huvide kontiinumi või tegevusega (Paveau 2011: 41). Seda ka näiteks Eesti kontekstis, nii minevikus kui ka tänapäeval. Need mittekeeleteadlased oskasid keelt kohandada mingi etteantud struktuuriga ning tõenäoliselt olid tuttavad eelkäijate keelekirjutistega. Niisamuti võib oletada, et nad kõnelesid mitut keelt (sh ladina keelt) ${ }^{1}$. Niisiis võib öelda, et need autorid olid omal moel asjahuvilised või amatöörid, ennekõike haritlased. Haridus on üks oluline tegur, mis inimese keeletaju mõjutab: haritumad inimesed usuvad enamjaolt vähem stereotüüpe, vähemalt oma eriala piires (Montgomery 2007: 177-178). Teisalt võib aga arutleda, et varasemad kinnistunud arusaamad lihtsalt asenduvad teiste, objektiivsematega. Inimeste püüded keelt kirjeldada rajanevad tahtlikult või tahtmatult mingil juba kujunenud traditsioonil. Seeläbi ollakse osa traditsioonist ja samuti selle edasikandja. Olgugi et keeleteadlane on oma arvamustes objektiivsem kui näiteks tavakõneleja, on temagi analüüsiotsused mõnikord kallutatud, otsides süsteemsust varasema teadmisega.

Peale hariduse lisandub teisigi individuaalseid tegureid, nagu vanus, sugu, haridus, sotsiaalne positsioon ja reisikogemus. Igal neist on oma mõju inimese murdetajule: vanemad inimesed seovad end sagedamini piirkondlike keelekujudega, niisamuti peavad mehed oma keelt ühiskeelest erinevamaks, naised sellega aga sarnasemaks. Kõrgem sotsiaalne positsioon paneb inimesi enamasti oma keelt pidama normipärasemaks ning reisimine avardab teadmisi keele varieerumisest. (Montgomery 2007: 177-178)

Inimese võimet tajuda ümbritsevat jagatakse kaheks: otsene ja vahendatud taju. Otsese taju korral saab inimene oma meelte kaudu infot ümbritseva kohta ise kohal olles, kaudset infot saab ta samuti oma meelte kaudu, aga mingisuguse teise meediumi vahendusel (kaardid, ajalehed, vestlused teiste inimestega jne). Kuigi meediumi teel saadu kätkeb juba teatavat valikut tervikust, ei erine otsese ja vahendatud informatsiooni

${ }^{1}$ Kuigi ka selles mõni analüüsitavate autorite kaasaegne kahtles. Näiteks heitis Heinrich Johann von Jannau oma teoses „Sitten und Zeit“ (1781) vaimulikele ette vähest huvi orientaallingvistika, täpsemini heebrea keele õppimise vastu. 
omandamine ja töötlemine (Downs, Stea 1974: 23-24). Kognitiivselt erinevad on hoopis mitmesugused seosed ja assotsiatsioonid, mida mingi paik esile kutsub ning mis on ruumiga nõrgemini seotud (ibid.). Objektide mõõtmed, asend ja kuju pole kujutluses samad kui tegelikkuses, mõõdetavas ruumis. Võrreldes kaht sama kaugel asuvat paika, tunduvad inimestele olulised kohad, keskused või nende naabruses asuvad alad lähemal, suuremad ning täpsemini piiritletud ja kujutatud. (ibid.: 17-18) Inimese taju iseloomustab lünklikkus: esindatud on ainult märgilised ja olulised objektid, millest inimene ruumis orienteerumisel juhindub. Inimesed kasutavad hulganisti n-ö konventsionaalseid ruumisümboleid, millest nad kas või ainult kuulu järgi on teadlikud, ent mis on tähtsad, kuna need on osa kollektiivsest traditsioonist. Niisamuti on inimese ruumitajus olulisel kohal üldistamine: sarnaseid paiku või ruume võrreldakse ja liigitatakse juba varasema kogemuse toel. (ibid.: 20) Neidsamu tegureid saab analüüsiks rakendada mis tahes ajaperioodil.

\subsection{Keelte ja murrete piiritlemist mõjutavad looduslikud ja inimtekkelised tegurid}

Kuigi artikli fookus on murrete liigendamisel ja mitte ajaloolisel kujunemisel, on siiski oluline teadvustada järgmises peatükis esitatud tegureid. Kuivõrd liigendamist võib pidada osaks keele korraldamisest, siis on kahtlemata keele piiride määramisel keelele endale markantne mõju. Seda enam, et tihtilugu langevad kokku haldusüksuste piirid ja looduslikud tõkked. Neid tegureid saab analüüsida kas autori kirjutatu või hilisemate interpretatsioonide põhjal. Selle artikli analüüsiosas on võimaluse korral püütud rakendada mõlemat.

Keelte ja murrete piiritlemist mõjutavaid tegureid on kahesuguseid: 1) looduslikud ja 2) inimtekkelised. Looduslikud tegurid on igasugused tõkked, mis pärsivad inimeste omavahelist läbikäimist (nt jõed, metsad, mäed). Inimtekkelised on halduskord ja -piirid, infrastruktuur (nt teed, sillad ja sadamad), erinevad usutõekspidamistel, etnolingvistilistel ja muudel põhimõtetel loodud rühmakuuluvussuhted; poliitilised kokkulepped, aga ka näiteks inimeste liikumise piiramine, käsitades inimesi õigusteta subjektidena; rahvastikumuutused, välja- ja sisseränne ning kaubandussuhted, mis niisamuti takistavad või keelavad suhtlust (Honkola 2016: 30; Kumagai 2016: 343). Need kaks kategooriat pole alati eraldatud: 
on oletatud järgnevust selles, kuidas looduslike tõkete piirav mõju avaldub hiljem halduspiirides (Saareste 1932: 20-21). Kuid samas on vastupidiseidki näiteid, kus keelepiirid ilmnevad vaid kogukonna teadliku (või hiljem traditsiooniks kinnistunud) tahte toel (nn group enforcement) ilma reaalsete looduslike tõketeta (Honkola 2016: 19). Slovakkia murdelugu uurinud Alexander Maxwell on näidanud, kuidas nii keeleteadlaste liigendustesse kui ka tavakõnelejate arvamustesse on kinnistunud traditsiooniline arusaam Slovakkia murrete kolmikliigendusest. See ei tekkinud mitte mõne keeleteadusliku töö põhjal, vaid kirjakeele reformi ümbritsenud religioossest konfliktist (Maxwell 2006: 162). Lähedane näide selle kohta Eestis on kas või Võru ja Setu murde eristamine sarnasel alusel.

Mõneti sarnases unustatud ja enesestmõistetavas olukorras on loodustõkete analüüs keele varieerumise uurimisel. Loodustõkkeid on käsitletud valdavalt kaht moodi. Esiteks, nagu Simon Pickl jt (2014: 25) on esile toonud, on murrete leviku analüüsimisel loodustõkkeid püütud eirata, arvestades murrete omavahelisi kaugusi linnulennult või lähtudes keelelisest, dialektomeetrilisest kaugusest. Sellise lihtsustatud lähenemise asemel arvutas Charlotte Gooskens (2012: 40-41) aga välja, kui palju aega kulus piirkondade vahel reisimiseks auriku, rongi või postitõllaga 1900. aastatel, ning võrdles seda ajalist kaugust keeleerinevustega. Tema uurimusest selgus, et reisiaegade kestuse ja tajutavate murdeerinevuste vahel on tugevam seos kui murdeerinevuste ja linnulennuliste kauguste vahel (ibid.: 44). Teiseks, loodustõkkeid on käsitletud deskriptiivselt, nentides nende olulisust murrete piiritlemisel, kuna need on takistanud inimeste liikumist ja seega soodustanud mingites piirkondades keelelist omapära. Alles viimasel ajal on kvalitatiivsete uurimuste ning ökolingvistilise ja -semiootilise lähenemisega hakatud loodustegurite ja keelte suhtele suuremat tähelepanu pöörama. Nii on näiteks leitud seoseid loodusliku liigirikkuse ja keelelise mitmekesisuse vahel: mida lähemal ekvaatorile, seda suurem on mitmekesisus nii keeles kui ka looduses (Mace, Pagel 1995; Moore jt 2002). Kasutades geneetikas tuntud fülogeneesimeetodeid, on Jaapani saarte puhul tõestatud, et ookean kui loodustõke on põhjustanud keelelist eripära. Samas möönavad autorid, et loodustõke oli küll keelemuutuse tekke algpõhjus, ent keele omapära säilimisel võivad olla teised mõjurid. (Lee, Hasegawa 2014: 1910)

Loodustegurite analüüsimisel on silma paistnud soome uurijad (Honkola jt 2013), kes on samuti fülogeneesimeetodeid kasutades uurinud, kas 
kultuur ja kliimamuutused on omavahelises seoses ja kas üks või teine on mõjutanud Uurali keelkonna muutumist. Analüüsitavate tegurite hulka kuulusid muu hulgas piirkondade keskmine õhutemperatuur, sademete hulk, lumikatte paksus, lumeperioodi pikkus, metsa osakaal piirkonnas, keskmine kõrgus merepinnast, järvede ja jõgede hulk ning mullastikutüüp. Kuigi nende uuringu tulemused olid samad mis varasematel (traditsioonilistel) murdekäsitlustel, täpsustasid need siiski keelkondade lahknemise aega. Niisamuti ilmnes nende analüüsist, et näiteks temperatuuri tõus võis väga tõenäoliselt olla keele varieeruvuse põhjustaja. Ilma soojenemise tõttu suurenes populatsioon, see omakorda soodustas väljarännet.

Nagu eespool viidatud uurimustest saab järeldada, ei ole inimtekkelised ja looduslikud tegurid eraldiseisvad. Niisama tuleb koos looduslike oludega arvestada ka inimeste eluviisi, selle muutumist (küttidest-korilastest karjakasvatajateks ja põllupidajateks) ning sotsiaalsete suhete eripära. Näiteks ei pruukinud põllumajanduseelses Eestis jõed olla rände looduslikuks takistuseks, pigem vastupidi. Esialgu Põhja-Eesti jõgede äärsed asundused laienesid ajapikku järjest enam veekogudest eemale, kui neis piirkondades nappis haritavat maad (Vedru 2004: 195). Uus elulaad muutis nendes kogukondades jõgede funktsiooni: argise elupaiga asemel tekkisid jõeorgudesse kalmud või kultuskohad. (ibid.: 196) Selline paiga tähenduse muutus elulisest igavikuliseks (religioosseks) ilmestab inimeste liikumist mitmel tasandil ja keele levikut mõjutavate võimalike faktorite keerukust.

\section{Murdekäsitlused XVI-XVIII sajandi allikates}

Selles peatükis analüüsitakse kõikvõimalikke tekste, kus on kirjeldatud kas murdeid, piirkondlikke eripärasid või esitatud murdekeele näiteid. Analüüsi eesmärk on esitada kronoloogiline murdelugu, lähtudes eelmises peatükis kirjutatust. Põhieesmärk on arutleda, kuidas murdeteadmine arenes ning mis seoseid võib autorite ja tekstide vahel leida. Vaadeldakse, kas murrete kirjeldustes tulevad esile sotsiaalsete või looduslike tegurite mõjud, mis andnud alust keelekujude piiramiseks. Kõnealused saksakeelsed tekstid olid suunatud just baltisaksa haritlastele ja õpetlastele alamrahva paremaks tundmaõppimiseks ning seeläbi omakorda viimaste harimiseks. Valdavalt olid teoste autorid pastorid, keda kannustas nii üldteaduslik huvi kui ka jumalasõna levitamine. Paljuski olid toonased 
keelekirjutised kantud ühtse kirjakeele loomise taotlusest. Kanooniliste keeleteaduslike teoste kõrval analüüsitakse siinses peatükis teisigi humanitaarteaduslikke, eeskätt ajalooalaseid tekste.

Esimene kirjalik allikas, milles on kirjeldatud Eesti murrete piirkondlikku paiknemist, on ühtlasi vanim eesti keelt sisaldav trükis, WanradtiKoelli katekismus 1535. aastast. Selle viimasel lünklikul ja paljuski rekonstrueeritud leheküljel on lühike saksakeelne kommentaar selle kohta, et Tartus, Tallinnas, Narvas ja Viljandis räägitakse erinevalt. Kõige õigemat keelt räägitavat aga hoopis Laiusel. (Weiss, Johansen 1930: 134) Teksti keelt analüüsinud Andrus Saareste on seda pidanud üldiselt idamurdeliseks, täpsemini Alutaguse murret esindavaks, küll aga mitte kitsalt Laiuse piirkonnale omaseks (Saareste 1930: 80). Seevastu peab Julius Mägiste katekismuse keelt hoopis loode-eestiliseks murdeks (Mägiste 1970: 62). Saareste on rõhutanud katekismuse keele sarnasust teiste vanemate allikate omaga, nagu Mülleri jutluste ja Stahli teostega, kuigi eeskujuks see neile olla ei saanud (kuna katekismuse trükk kõrvaldati käibest). Saareste oletab siiski kirjakeele teatava traditsiooni olemasolu, mis eeldatavasti levis vaid käsikirjade kaudu. (Saareste 1930: 94)

Simon Wanradt oli pärit Saksamaalt, Klevest, õppis Wittenbergis ning oli vaimulik nii Tartus kui ka Tallinnas. Väidetavalt resideerus ta vähemalt 1538. aastal ka Läänemaal Tolli mõisas, seejärel Viljandis ning 1540. aastatel Paides ja Lemsalus. (Weiss, Johansen 1930: 99) Johann Koellil võis samuti olla sidemeid (või juuri) Viljandimaal, oletab Saareste, kuna tema perekonnanime variant (Köll) on seal laialt levinud (Saareste 1930: 73). Koell oli 1520. aastatel Olevistes mittesaksa (sks undeutcher) jutlustaja ning hiljem Püha Vaimu koguduse vaimulik (Weiss, Johansen 1930: 100). Niisiis on põhjust oletada, et vähemalt Wanradtil oli isiklik kogemus ja kokkupuude eri piirkondade keelekujudega. Kindlamini saab seda väita Tartu, Tallinna ja Viljandi puhul. Võimalik, et nad elasid-reisisid Narvas ja Ida-Eestis. Niisamuti võisid autorid olla teadlikud Narva lähistel kõneldavast keelest kelleltki kuuldu põhjal. Kui jääda Saareste sõnade juurde, et katekismuse keel on idamurdeline ja just alutaguselik, siis tähendaks see lähemat ja pikemat kokkupuudet sealse piirkonnaga. Sel juhul oleks arusaadavgi Laiuse nimetamine keeleideaaliks, kuna see jääb osaliselt idamurde alla.

Keele varieerumine on liigendatud valdavalt linnade järgi. Kihelkonna või asula täpsusega on nimetatud koht, mis on liigenduses olulisema 
(võib-olla ka isiklikuma) tähtsusega. Linnad kui haldusvõimu, kaubanduse, trükikunsti ja religioossed keskused esindavad teatavat piirkonda, hallates ümbritsevaid alasid (sama analoogiat võib näha muudegi haldusüksuste nimetamise puhul, nagu Tartu ja Tartumaa). Valdavalt ei elanud linnades eestlased, kelle keelt on tegelikult kirjeldatud, mistõttu võib tunduda kummastav selline liigendusvalik. Ilmselt on linnade järgi liigendada ka lihtsalt mugav: arvestades seda, kui lühike osa katekismusest on pühendatud keelekirjeldusele, ei püüagi see täita hõlmava ülevaate staatust. Täpsemaid murrete ulatusi teadmata ja toetudes (oletatavasti) peamiselt oma ebasüstemaatilistele tähelepanekutele on linnade järgi nimetamine täitnud oma funktsiooni: murrete paiknemine on tähistatud ja piirkondlik eristus murrete vahel loodud. Katekismuses pole kirjeldatud, mis suhtes nende linnade keelekujud omavahel on. Siiski on juba sellestki näha mitut peamist Eesti murdepiirkonda, mida hilisemad süstemaatilisemad keeleuurimused on kinnitanud.

Esimene keeleteaduslik teos, kus Eesti murretest on pikemalt juttu, on Heinrich Gösekeni 1660. aastal ilmunud „Manuductio ad Linguam Oesthonicam“. Göseken sündis Saksamaal Hannoveris ja õppis 1630. aastatel usuteadust Rostocki ülikoolis. Alates 1637. aastast elas ja tegutses Göseken Eestis. (Kingisepp jt 2010: 12-13) Gösekeni eeskujuks oli Heinrich Stahl ja tema 1637. aasta teos „Anführung zu der Esthnischen Sprach“. Oma teose eessõnas kirjutab Göseken (1660), et on Stahli sõnavara täiendanud Johannes Gutslaffi grammatikast „Observationes Grammaticae circa Linguam Esthonicam“ (1648) leituga. Viimati mainitud trükis täiendas Gösekeni eesti keele sõnavara ja küllap selle põhjal tegi ta ka oma murdeüldistused. Gutslaff ise on oma teoses murrete paiknemist ja omavahelist suhet kommenteerinud napilt. Ta mainib Tartu murret ja ,rasket“" ranniku murret/ keelt. Esimest kutsub Gutslaff oma grammatika (1648) eessõnas üles ka kasutama ja selle eest hoolt kandma, kuna see on tema sõnul „kodupaiga keel“. Teistegi autorite puhul on näha tuttavama keele eelistamist.

Göseken esitab esimesena põhjalikumaid kommentaare keele varieeruvuse kohta. Küll aga ei leia tema teosest terviklikku murdeliigendust ega -käsitlust. Kuigi Gösekeni sõnul on igal kihelkonnal ja piirkonnal iseäralikke sõnu, on ta täpsemalt ja pikemalt kirjutanud viiest Põhja-Eesti piirkonnast: Läänemaa, Virumaa, Järvamaa, Harjumaa ja Tartu.

Kõige puhtamat, st Gösekeni mõistes sõnalaenudest vabamat keelt (sks die reineste Sprache) räägitakse Gösekeni meelest Läänemaal, kus ta 
ise suurema jao oma elust vaimulikuna tegutses. Seega soovitab ta võtta omaks Läänemaa sõnu, kuna need on head eesti keele sõnad. (Göseken 1660: 5) Gösekeni hinnang keele puhtusele ja sellest tulenevale õigsusele pole aga järjepidev. Isegi Läänemaa keele puhul tõdeb Göseken vähest (sic!) läbikäimist saarlaste ja hiidlastega. Teiste maakondade puhul räägib Göseken keelekontaktidest, nii välis- kui ka siselaenudest: Virumaa laenab ingerlastelt, Järvamaa tartlastelt ning Harjumaa tallinlastelt ja seal elavatelt soomlastelt (ibid.: 5). Kõik nimetatud keelekontaktid on lähinaabritega. Küllap püüab Göseken sellega väita, et need piirkonnad on vähem oma murdelist omapära säilitanud, jättes täiesti tähelepanuta saksa, rootsi ja teiste struktuurilt võõramate keelte mõju.

Tallinna ja Tartu nimetamine omaette annab aimu sealsetest juba eristuvatest iseloomulikest (linna-) keeltest. Ilmekalt tuleb see esile Harjumaa ja Tallinna vastandusest, ent sama võib oletada Tartu ja Tartumaa puhulgi. Gösekeni teoses on eraldi peatükk, mis loetleb mõningaid Tartu murde häälikulisi erinevusi muu (täpsustamata) põhjaeestilise piirkonnaga võrreldes, nt sain pro sein, kiel pro keel, tettut pro techtut, latz pro laps, kützeda pro küpseda. Nende kahe argumendi põhjal näeb jällegi Tallinna ja Tartu eripära väga selget kohta tollases murdetundmises. Göseken esitab teisigi keelenäiteid. Paljude puhul ei nimeta ta täpset piirkonda, kus neid kasutatakse (nt nahrlick, petzick, weydrick, kiriow siuck, sissalick, nartzick, sabel, kehje peck, kahje laba). Mitmed näited on aga siingi esitatud Tallinna-Tartu vastandusena (nt tarre-tubba, penni-koyr). (ibid.: 77)

Gösekeni grammatikas on uudne maakondade kaupa keele piiritlemine ja juba ka sõnaselge murrete eristamine. Olenemata sellest, et Gösekenil on eraldi Tartu murret kirjeldav peatükk, on tema teoses põhjalikumalt (ent endiselt mitte väga süsteemselt) kirjeldatud põhjaeesti murrete liigendust. Wanradti-Koelli katekismusega sarnaneb Gösekenil Tallinna ja Tartu vastandusest rääkimine.

Kui palju oli Göseken mööda Eestit rännanud ja eri piirkondadest murdematerjali kogunud, pole lõpuni selge. Kindel on see, et ligi 40 aastat elas ta Kullamaal, enne seda Läänemaal ja Tallinnas (Kingisepp jt 2010: 14). Gösekeni puhul on aga tõendatav vahendatud taju roll tema murdekäsitluses: olgugi et Stahlil ja Gutslaffil on vähe metamärkusi murrete liigenduse kohta, on nende autorite tähelepanekud keele kohta ja kogutud sõnavara olnud Gösekeni murdeloo allikas. Kahtlemata oli teisigi, kellelt võis Göseken murdekeelt kuulda, olgu selleks kas või tema 
kolmas, Saaremaalt pärit naine. Kuid iga dokumenteerimata vestluse mõju on paraku võimatu arvesse võtta.

Arvamusi ja kirjeldusi eesti keele liigitamise kohta leiab ajalookirjandusestki. Nii on näiteks paarkümmend aastat hiljem (1695) kirjutanud murretest Christian Kelch teoses „Liefländische Historia“. Kelch õppis Frankfurdis ajalugu ja Rostockis teoloogiat. Hiljem töötas ta mitmel pool Eesti- ja Liivimaal koduõpetaja ja vaimulikuna. (Napiersky, von Recke 1829: 419) Kelch arvas, et eesti ja soome keel jagavad (osalt) sõnavara, mistõttu on nad arvatavasti ühist algupära. Küll aga ei nimetanud ta neid murreteks. Samasuguses suhtes on tema teoses eesti ja liivi keel. Liivlasi peab Kelch üheks endiseks Eesti rahva osaks. (Kelch 1695: 12-13) Huvitaval kombel on näha samasuguseid ideid ja tõlgendusi hilisemates ajalookirjutistes. Sellised üldteaduslikest huvidest kantud teosed näitlikustavad hästi toonast teaduste teket ning seda, kuidas erinevate eesmärkidega tekstid (nt kas dokumenteerida keelt või ajalugu) täiendasid üksteist teemade, näidete ja arutlustega. Nagu hiljem näha, on sellisele keeleteadmiste vahetamisele iseloomulik kumuleeruda ülevaatlikumatesse teostesse.

XVIII sajandi esimesel poolel ilmunud Anton Thor Helle teoses „Kurtzgefasste Anweisung zur Ehstnischen Sprache“ (1732) pole murrete süstemaatilist liigitust. Harjumaal sündinud ning põhiliselt sealsamas elanud ja töötanud Helle on maininud paaril korral Läänemaa, Harjumaa, Virumaa, Põltsamaa ja Järvamaa keelekujude morfoloogilisi või häälduslikke erinevusi, jätkates juba kujunevat tava liigendada murdeid maakonniti. Helle grammatikas on eraldi murrete peatükk, ent selles loetleb ta vaid murrete häälikulisi erinevusi, kuid ei täpsusta, mis murdes või isegi mis piirkonnas selliseid erijooni leidub (Helle 1732: 80). Nende hulgas on näiteid nii põhjaeesti kui ka lõunaeesti murretest, valdavalt aga Lääne- ja Kirde-Eestist.

On arvatud, et Helle sõnaraamatki toetus sekundaarkirjandusele (vt nt Kask 1955). Sõnaraamatuosa tuginevat näiteks Pärnust pärit Salomo Heinrich Vestringi XVIII sajandi mõjukale käsikirjalisele eesti-saksa sõnaraamatule. Vestring on samuti märkinud mõningate eestikeelsete sõnade järele kohatähiseid, mistõttu saab sõnaraamatut lehitsedes koostada tingliku murdeliigenduse. Ka Vestring on liigendanud murdeid maakonniti (Harjen ehk Harjumaa, Wieck ehk Läänemaa, Jerwen ehk Järvamaa, Wierland ehk Virumaa, teisisõnu needsamad piirkonnad, mida Hellegi välja tõi) ja linnade kaupa (Reval ehk Tallinn, Oberpahlen ehk Põltsamaa). Eraldi 
Tartu murde sõnade loetelust võib järeldada, et sellelgi oli määrav tähtsus tema liigenduses. Niisamuti on Vestring tähistanud üksikuid kodukandile omaseid keelendeid täpsemalt (nt Tackerort ehk Tahkuranna, Gudmansbach ehk Häädemeeste ja Salis ehk Salatsi).

Mõnikümmend aastat hiljem ilmunud järjekordses Liivimaa ajaloos „Der Liefländischen Chronik“ sõnab Johann Gottfried Arndt (1753: 10), et liivi keel on murtud (sks gebrochener) Tartu murre. Arndt omandas kõrghariduse Halles ja töötas Liivimaal koduõpetajana, Kuressaares rektorina ja Riia lütseumis korrektorina (Napiersky, von Recke 1827: 41) Oma kroonikas sõnab Arndt, et tal olevat näiteid pastor Johann Conrad Vurchardilt (neid ta küll paraku ei esita), kinnitamaks tema väidet liivi keele ja Tartu murde seose vahel (Arndt 1753: 10). Sellegi ajalookirjutise puhul on näha suundumust kirjeldada liivi ja eesti keele suhet põlvnemisena, seekord siis aga murdeparadigmas. Kuivõrd varasemad keelekirjutised püüavad valgust heita rohkem eesti keele sisesele liigendusele, siis (Liivimaa) ajaloo teosed paigutavad eesti keele ja selle murded mingisse suuremasse süsteemi, sedagi murde ja keele vahekorra aspektist. Seniste ajalookirjutiste põhjal saab väita, et eesti keel on keele staatuses ning ülemmõisteks murdeks taandatud liivi keelele.

Kõige põhjalikumalt on sellel perioodil Eesti murdeliigendust käsitlenud August Wilhelm Hupel teose „Ehstnische Sprachlehre fuer beide Hauptdialekte, den revalschen und doerptschen; nebst einem vollstaendigen Woerterbuch" kahes trükis $(1780,1818)$. Hupel sündis Saksamaal Buttelstedtis, õppis Weimari gümnaasiumis ja Jena ülikoolis (Jürjo 2004: 31-33). Oma grammatikas, mis mõne autori hinnangul toetub Hellele (vt ibid.: 381), liigendab ja piiritleb Hupel nii pea- (sks Hauptdialekte) kui ka kõrvalmurdeid (sks Nebendialekte). Eesti keel aga olevat soome keele õde (selles näib Hupel olevat isegi kindlam teises trükis) (Hupel 1780: 4). Väikseim murdeüksus Hupeli liigenduses on kihelkond, ent peamiselt kirjeldab Hupel keele varieerumist toonaste suuremate haldusüksuste, kreiside, hertsogkondade, provintside ja maakondade abil.

Hupeli sõnul kõneldakse Tallinna murret Eesti hertsogkonnas, Saaremaa provintsis, Pärnu kreisis ja osalt Tartu kreisiski. Tartu murret aga kõneldakse kahes (teise trüki järgi ühes) praostkonnas ehk 17 Tartu kreisi kihelkonnas ning see ulatub ka naaberaladele (ibid.: 5).

Hupeli grammatikas on seni kõige detailsem murdekirjeldus. Tallinna peamurde alla kuuluvad Hupeli kohaselt Harju, Läänemaa, Põltsamaa ja 
Peipsi, kuid ka Järva ja Viru kõrvalmurre. Peipsi ja Viru on justkui üleminekualad: mõlemas on palju Tartu sõnu. Peipsi murret kõneldavat Peipsi järve kaldal, aga ka Kodavere, Maarja-Magdaleena ja Torma kihelkonnas, kõige iseäralikumaid vorme leiab aga Alatskivilt. (ibid.: 5)

Peipsi murde puhul on näha veidi erandlikku malli: murde nimetus ei ole seotud haldusüksusega, vaid mingi piiritleva või ühendava loodusobjektiga - Peipsi järvega. Murdenimetuse seotus loodusobjektiga loob erandi ja annab edasi omamoodi konnotatsiooni: murde rannarahvapärasus ning järv kui kogukondliku sidususe looja, millel on defineeriv mõju isegi veidi kaugematele aladele (sellest ka ulatumine lähikihelkondadesse).

Tartu murde alla kuuluvad Otepää, Rõuge ja Räpina kõrvalmurre. Puhtaimat Tartu murde kuju kõneldaksegi Otepääl (ibid.: 5). Palju täpsemalt Hupel Tartu murret ei liigenda. Hupeli Tartu murde käsitlus arvatakse toetuvat Johann Christoph Clare käsikirjale (Jürjo 2004: 381). Toetumine sekundaarkirjandusele võib seega seletada, miks Tartu murde sisemine liigendus on teistmoodi struktuuriga kui Tallinna murde oma. Näiteks pole Hupel Tallinna murde puhul kirjutanud, kui paljudes või mis kihelkondades seda keelekuju kõneldakse.

Üldistatuna võib Hupeli liigenduses peamurdepiiri seada Kodavere ja Maarja-Magdaleena kihelkonna lõunapiirile ning läänes Võrtsjärvele. Hupel elas ja töötas oma seatud peamurdepiiri läheduses: Äksis ja Põltsamaal (hiljem ka Paides). Tema peamurdepiiri paigutus vastab küllaltki täpselt hilisematele käsitlustele. Niisiis võis siingi olla roll oma kodukoha vahetul tundmisel. Kubermangupiiril pole Hupeli peamurrete piiritlemisele ainumääravat mõju: Tallinna murret kõneldakse nii ühes kui ka teises kubermangus. Kuigi selle liigenduse järgi kuuluvad Saaremaa ja Pärnu kreis samuti Tallinna murde alla, ei nimeta Hupel neid siiski kõrvalmurreteks.

Eraldi tähelepanu pöörab Hupel Pärnu murdele, mida ta iseloomustab kui segu Tallinna ja Tartu peamurdest, millel on siiski rohkem Tallinna murde jooni. Küllap on nn Pärnu murre tallinlikum seetõttu, et seda kõneldakse suuresti Läänemaal. (Hupel 1780: 5) Hupel ei täpsustanud Pärnu murde sisemist jaotust, aga on võimalik, et sealt kumab läbi Mulgi murre (ehk Hupeli nimetatud sarnasus Tartu murdega), mis on liidetud Pärnu murdega. Oma grammatika teises, 1818. aasta trükis täpsustab Hupel, et Pärnu murre ulatub kuni Viljandi linnani (Hupel 1818: 16). Küll aga ei kirjuta ta Mulgi murdest veel ka siin mitte. 
Hupel oli kursis Gösekeni käsitlusega ning oma grammatika teises trükis tsiteerib ta Gösekeni murdemärkusi, mis puudutavad võõrkõlalisi sõnu mingil murdealal (Hupel 1818: 16). Sarnane aga Hellega on Hupelil näiteks see, et mõlemad mainivad Läänemaa, Harjumaa ja Järvamaa murdeala. Seega on näha toetumist varasemale murdekirjandusele ning mingisuguse traditsiooni kujunemist. Ent samas on Hupel ka ise mitme traditsiooni algataja. Niisamuti on Hupel grammatika teises trükis täiendanud oma murdekirjelduse sissejuhatust liivi keele ümber käinud arutlusega, öeldes, et mõni (tekstis konkreetselt nimetamata, aga eeldatavasti ka needsamad ajalookirjanduse autorid ja nende mõtete edasiarendajad) on pidanud liivi keelt kolmandaks peamurdeks. Hupeli arvamuse järgi oli liivi keel sarnane kas Tartu või pigem Pärnu murdega.

1790. aastatel ilmuvad kahel autoril Eesti- ja Liivimaa ajalugu käsitlevad teosed. Esimene neist on baltisakslase Heinrich Johann von Jannau „Geschichte von Lief- und Ehstland“ (1793), teine Ingerimaal sündinud Rootsi päritolu Thomas Hiärne „Ehst-, Liv- und Lettländische Geschichte“ (1794). Mõlemad teosed järgivad juba varem alguse saanud ajalookirjutiste traditsiooni, kus eestlasi ja soomlasi arvatakse olevat üht algupära. Jannau nimetab eesti keelt soome keele murdeks, mida kõneldakse Saaremaast Valgani, täpsemini Luke, Apelkalnsi ja Härgmäe kihelkonnani (Jannau 1793: 4) Jannau keelekäsitlus on seni nimetatud ajaloolaste omadest kõige üldistavam. Niisamuti on Jannau tuttavlikult sidunud keele varieerumise kihelkondadega. Tema kirjelduses on selge hierarhiline suhe keelte vahel, seda ka eesti ja liivi keele puhul: liivi keel on tema sõnul moondunud eesti keele murre, mis (oletatavasti) tekkis siis, kui saarlased jäid paikseks Kuramaale ning nende keel segunes kohalike omaga.

Hiärne aga ütleb, et eesti ja soome keele vahel on vaid murdeerinevused. (Hiärne 1794: 17) Hiärne teoses on kirjeldatud küll sarnast olukorda, kuid ilma sõltuvussuhteta: mõlema keele vahel on murdeerinevused, ent pole öeldud, et üks on teise murre ehk ühe kategooria olemasolu (murre) ei sõltu ülemmõistest (keel). Hjärne nimetab kohalikku keelt eba- või mittesaksaks (sks undeutsch). Tema sõnul nimetavad baltisakslased sel moel nii eesti kui ka läti keelt.

Seda usutavasti laialt levinud kategoriseerimist seletab täpsemalt Hupel 1795. aastal ilmunud teoses „Idiotikon der deutschen Sprache in Lief- und Ehstland“. Hupel esitab seal definitsiooni termini ebasaksa või mittesaksa kohta: see pole saksa, vene ega rootsi keel ning sellega 
märgitakse vaid eesti või läti keelt (Hupel 1795: 244). Analoogseid näiteid on teisigi: esimeste läti keelde tõlgitud teoste (1586) pealkirjadeski oli mainitud, et tõlge on saksa keelest mittesaksa keelde (sks aus dem Deutschen ins Undeutsche); liivlasi nimetati mittesakslasteks Riia gildi dokumentides XIV sajandil (Bojtár 1999: 129). Hupeli definitsioonist on aru saada, et terminil ebasaksa või mittesaksa on suur sotsiolingvistiline ja keelepoliitiline kaal. Selle alla ei kuulu ükski suure riigi või valitsejate keel. Seega on sellega tähistatud vaid kohalikku madalamat ja funktsioonide poolest piiratumat keelekuju. Murdeliigenduste sotsiolingvistilises analüüsis on seetõttu veel üks tasand, millega arvestada: on eliidi keel, mis on justkui rohkem keel, ja alamate keel, mis on mitteeliidi keel, väärimata keele staatust, ning siis veel murded.

Kuigi murdeeristuste ajalugu algab tinglikult Wanradti-Koelli katekismusega, ei olnud sel kaotsi läinud teosel hilisematele autoritele mõju. Mitme piirkonna puhul siiski kattusid katekismuse murdeliigendus ja hilisemad liigendused, teiste puhul mitte (nt tähelepanuta jäänud Narva, mille asemel kõneldi laiemalt Virumaast). Alati eristati Tartu ja Tallinna murret, seda just linnakeele eripära arvestades. Selline murrete ja keele eristamine ühe piirkonna sees peegeldab ühtse kirjakeele loomise vajadust, mis mõjutab kogu arusaama keele liigendamisest. Valdav sisuline murdeüksus oli vaadeldud perioodil maakond. Kuigi nimetati teisigi haldusüksuseid, näiteks kihelkondi, jäid need umbmäärasemaks. Tänapäevaks domineeriv kihelkondlik murdeliigendus ei jäänud tollal kindlasti keelematerjali vähesuse taha: selle tõestuseks olgu kas või suuremahulised sõnastikud. Küllap olid maakonnad piisavalt suure üldistusastmega, kasutuskõlblikud ja hoomatavad üksused, mille ajalooline taust (kihelkondade ühinemine maakondadesse) sobis kompaktselt kirjeldama siinset keelekeskkonda.

Hupeli kahes trükis ilmunud koguteos on hea näide tekstide ja mõtete kumulatiivsuse kohta. Kuid enne sedagi on ühiste huvidega autorid andnud üksteise teostele innustust või lausa ainest, olgu siis seda otsesõnu nimetades või mitte. Arvestades väheseid ilmunud trükiseid, oli see ootuspärane. Hupeli grammatika aga ühendas endas ajalookirjandusestki pärit keele- ja murdearutlusi. 


\section{Kokkuvõte}

Kuigi vaadeldud perioodi pikkus oli mitu sajandit ning sellel jooksul vahetus riigivõim ja muutusid sotsiaalsed olud, ei toimunud murdeliigenduste kirjeldamises midagi revolutsioonilist. Samu haldusüksusi kasutasid eri päritolu ja haridusega autorid samamoodi edasi. Koloniaallingvistika vaimus keeleparandus, mida saatsid tajudialektoloogilised hinnangud ja arvamused, tuli murrete liigendamises selgelt esile, näiteks kas või selles, kus arvati puhtaimat murdekuju räägitavat või mis murret peeti kõige ehedamalt eestipäraseks (st võorlaenuvabaks). Murdeliigenduste vahekord loodustõketega oli analüüsitud tekstides peaaegu olematu: võimalik, et ainult Hupel nimetas üht kõrvalmurret Peipsi järve järgi. Teoreetilisi käsitlusi loodus- ja sotsiaalsete tõkete (nt alamate liikumispiirangud) mõjust keelele aga polnud. Valitud metoodika lubas analüüsida eri haldusüksuste esiletulekut murrete liigendamisel vaadeldaval perioodil: mis olid need haldusüksused, mille põhjal murdeid liigendati ning kuidas nende kasutus kinnistus või muutus. Metoodika ei võimaldanud aga veenvalt põhjendada valikuid, mida murrete kirjapanijad liigendamisel tegid.

Kuni XIX sajandi alguseni esines eesti keele ja selle murrete liigendamises kaks suuremat suundumust. Mitmed ajalookirjutised püüdsid kirjeldada eesti keelt ja selle sugulaskeeli murdeparadigmas. Sageli peeti sel puhul soome keelt eesti keele ülemmõisteks (st eesti keel on soome keele murre) ning liivi või mõnda muud väiksemat läänemeresoome keelt omakorda eesti keele murdeks. Selline liigitus ei tuginenud usutavasti vaid keeleomapärale, vaid ka territooriumi ja populatsiooni suurusele või mõnele täpsustamata sotsiokultuurilisele tegurile.

Keelekeskne kirjandus tundus arenevat sellest aga esialgu eraldi. Arvestades trükis ilmunud ja käsikirjaliste keelekäsitluste mahtu, oli vaid väike osa sellest pühendatud murrete liigitamisele. Väheste metamärkuste põhjal saab aga järeldada, et murded olid seotud toonase halduskorraga, kuid see suhe polnud tingimata piirav, nagu tõestas Hupeli käsitlus peamurdepiirist, mis väga selgelt erines näiteks Eestimaa-Liivimaa kubermangupiirist. Siiski ei pidanud ükski autor vajalikuks põhjendada haldusüksuste ja murdealade seotust. Nende kahe üksteist täiendav suhe tundus iseenesest mõistetavana ja kandus juba peaaegu traditsioonina ühest tekstist teise. Peamiselt eristati kirjanduses Tallinna ja Tartu murret. Nende kahe nimetamine linnade järgi aga võis tähistada enamat kui vaid 
keskuste abil suurema piirkonna liigendamist. Nii näiteks võib oletada nendele linnadele iseloomulike murdekeelte olemasolu ja olulisust kirjakeeltena kogu keelestruktuurile.

XIX sajandi jooksul hoogustus jõudsalt murdeuurimine ja seda käsitleva kirjanduse väljaandmine ning XX sajandil sai alguse juba süstemaatiline keeleteadus Eestis. Siiski ei tekkinud kumbki tühjalt kohalt, vaid murdeteadmine kumuleerus ajapikku asjaarmastajatelt teadlikumatele kirjutajatele.

Artikli teemat saaks kahtlemata edasigi arendada, kaasates sotsiolingvistilisse uurimisse rohkem tollaste sõnaraamatute keelendeid ja nende piirkondlikku kindlaksmääramist. Niisamuti pole välistatud, et on teisi, vähem levinud allikaid, mida selles artiklis ei kajastatud. Sellegipoolest annab siinse artikli analüüs süsteemse alguspunkti hilisemate murdeliigenduste ja nende tagamaade uurimiseks.

\section{Kirjandus}

Arndt, Johann Gottfried 1753. Der Liefländischen Chronik Andrer Theil von Liefland unter seinen Herren Meistern, welche die alte Geschichte des Ordens und der benachbarten Völker erleutert. Halle: Johann Justinus Gebauer.

Auer, Peter 2005. Europe's sociolinguistic unity, or: a typology of European dialect/standard constellations. - Perspectives on Variation. Sociolinguistic, Historical, Comparative. Eds. Nicole Delbecque, Johan van der Auwera, Dirk Geeraerts. (= Trends in Linguistics. Studies and Monographs 163.) Walter de Gruyter, 7-42.

Blommaert, Jan 2013. Ethnography, Superdiversity and Linguistic Landscapes. Chronicles of Complexity. Bristol: Multilingual Matters. http://dx.doi. org/10.21832/9781783090419.

Bojtár, Endre 1999. Foreword to the Past. A Cultural History of the Baltic People. Budapest: Central European University Press.

Downs, Roger M., David Stea 1974. Image and Environment. Cognitive Mapping and Spatial Behavior. Arnold.

Errington, Joseph 2001. Colonial linguistics. - Annual Review of Anthropology 30 (1), 19-39. http://dx.doi.org/10.1146/annurev.anthro.30.1.19.

Fanon, Franz 2004. The Wretched of the Earth. New York: Grove Press.

Gooskens, Charlotte 2012. Non-linguists' judgments of linguistic distances between dialects. - Dialectologia 9, 27-51. 
Gutslaff, Johannes 1648. Observationes Grammaticae circa Linguam Esthonicam. Tartu: Johannes Vogel.

Göseken, Heinrich 1660. Manuductio ad Linguam Oesthonicam, Anführung zur Öhstnischen Sprache, Bestehend nicht alleine in etlichen praeceptis und observationibus, Sondern auch In Verdolmetschung vieler Teutschen Wörter. Der Öhstnischen Sprache Liebhabern mitgetheilet. Reval: Adolph Simon.

Habicht, Külli 2003. Vana kirjakeele uurimine. - Emakeele Seltsi aastaraamat 48 (2002). Eesti keele uurimise analüüs. Koost. Mati Erelt. Tallinn, 135-165.

Haugen, Einar 1966. Dialect, language, nation. - American Anthropologist 68 (4), 922-935. http://dx.doi.org/10.1525/aa.1966.68.4.02a00040.

Helle, Anton Thor 1732. Kurtzgefasste Anweisung zur Ehstnischen Sprache, in welcher mitgetheilet werden I. Eine Grammatica. II. Ein Vocabularium. III. Proverbia. IV. Ænigmata. V. Colloquia. Halle: Stephan Orban.

Hiärne, Thomas 1794. Thomas Hiärns Ehst-, Liv- und Lettländische Geschichte. Nach der Originalhandschrift herausgegeben. I. Mitau: Johann Magnus Wehrt.

Honkola, Terhi 2016. Macro- and Microevolution of Languages: Exploring Linguistic Divergence with Approaches from Evolutionary Biology. (= Turun yliopiston julkaisuja, sarja A II, 311.) Turun Yliopisto.

Honkola jt 2013 = Terhi Honkola, Outi Vesakoski, Kalle Korhonen, Jyri Lehtinen, Kaj Syrjänen, Niklas Wahlberg. Cultural and climatic changes shape the evolutionary history of the Uralic languages. - Journal of Evolutionary Biology 26 (6), 1244-1253.

Hupel, August Wilhelm 1780. Ehstnische Sprachlehre fuer beide Hauptdialekte, den revalschen und doerptschen; nebst einem vollstaendigen Woerterbuch. Riga, Leipzig: Johann Friedrich Hartknoch.

Hupel, August Wilhelm 1818. Ehstnische Sprachlehre für die beyden Hauptdialekte, den revalschen und dörptschen, nebst einem vollständigen ehstnischen Wörterbuche. Zweyte durchgängig verbesserte und vermehrte Auflage. Mitau: J. F. Steffenhagen uns Sohn.

Hupel, August Wilhelm 1795. Idiotikon der deutschen Sprache in Lief- und Ehstland. Nebst eingestreueten Winken für Liebhaber. Riga: Johann Friedrich Hartknoch.

Jannau, Heinrich Johann von 1781. Sitten und Zeit. Ein Memorial an Lief- und Ehstlands Väter. Riga: Johann Friedrich Hartknoch.

Jannau, Heinrich Johann von 1793. Geschichte von Lief- und Ehstland pragmatisch vorgetragen. I. Riga: Johann Friedrich Hartknoch.

Jürjo, Indrek 2004. Liivimaa valgustaja August Wilhelm Hupel 1737-1819. Tallinn: Riigiarhiiv. 
Kaljundi, Linda, Ulrike Plath 2017. Eesti ajalookirjutus põimitud perspektiivist. - Tuna. Ajalookultuuri ajakiri 1, 2-6.

Kask, Arnold 1955. S. H. Vestringi eesti-saksa sõnaraamat ja selle osa eesti leksikograafias. - Tartu Riikliku Ülikooli toimetised 38. Ajaloo-keeleteaduskonna töid. Tartu: Tartu Riiklik Ülikool, 181-192.

Kask, Arnold 1984. Eesti murded ja kirjakeel. (= ENSV Teaduste Akadeemia Emakeele Seltsi toimetised 16.) Tallinn: Valgus.

Keevallik, Leelo, Karl Pajusalu 1995. Linguistic diversity and standardization in Estonian. The history of the active past participle. - Dialectologia et Geolinguistica 1995 (3), 13-41.

Kelch, Christian 1695. Liefländische Historia, oder Kurtze Beschreibung der Denckwürdigsten Kriegs- und Friedens-Geschichte Esth-, Lief- und Lettlandes. Revall: Johann Mehner; Rudolphstadt: Heinrich Urban.

Kingisepp jt $2010=$ Valve-Liivi Kingisepp, Kristel Ress, Kai Tafenau. Heinrich Gösekeni grammatika ja sõnastik 350. Toim. Külli Habicht, Külli Prillop. Tartu: Tartu Ülikool.

Kumagai, Yasuo 2016. Developing linguistic Atlas of Japan database and advancing analysis of geographical distributions of dialects. - The Future of Dialects. Selected Papers from Methods in Dialectology XV. Eds. Marie-Hélèn Côté, Remco Knooihuizen, John Nerbonne. (= Language Variation 1.) 333-362.

Laidla, Janet 2017. Ajalookirjutust mõjutanud tegurid varauusaegsel Eesti-, Liivi- ja Kuramaal. (= Dissertationes historiae Universitatis Tartuensis 44.) Tartu Ülikool. Tartu Ülikooli Kirjastus.

Lee, Sean, Toshikazu Hasegawa 2014. Oceanic barriers promote language diversification in the Japanese Islands. - Journal of Evolutionary Biology 27 (9), 1905-1912. http://dx.doi.org/10.1111/jeb.12442.

Mace, Ruth, Mark Pagel 1995. A latitudinal gradient in the density of human languages in North America. - Proceedings of the Royal Society of London B: Biological Sciences 261 (1360), 117-121. http://dx.doi. org/10.1098/rspb.1995.0125.

Maxwell, Alexander 2006. Why the Slovak language has three dialects: a case study in historical perceptual dialectology. - Austrian History Yearbook 37, 141-162.

Montgomery, Chris 2007. Northern English dialects: a perceptual approach. University of Sheffield.

Moore jt 2002 = Joslin L. Moore, Lisa Manne, Thomas Brooks, Neil D. Burgess, Robert Davies, Carsten Rahbek, Paul Williams, Andrew Balmford. The distribution of cultural and biological diversity in Africa. - Proceedings of the Royal Society of London B: Biological Sciences 269 (1501), 1645-1653. http://dx.doi.org/10.1098/rspb.2002.2075. 
Mägiste, Julius 1970. Vanhan kirjaviron kysymyksiä. Tutkielmia viron kirjakielen varhaisvaiheista 1200-luvulta 1500-luvun lopulle. (= Tietolipas 64.) Helsinki: Suomalaisen Kirjallisuuden Seura.

Napiersky, Karl Eduard, Johann Friedrich von Recke 1827. Allgemeines Schriftsteller- und Gelehrten-Lexikon der Provinzen Livland, Esthland und Kurland. I. Bearb. von J. F. v. Recke und K. E. Napiersky. Steffenhagen.

Napiersky, Karl Eduard, Johann Friedrich von Recke 1829. Allgemeines Schriftsteller- und Gelehrten-Lexikon der Provinzen Livland, Esthland und Kurland. II. Bearb. von J. F. v. Recke und K. E. Napiersky. Steffenhagen.

Paveau, Marie-Anne 2011. Do non-linguists practice linguistics? - AILA Review 24 (1), 40-54.

Pickl jt 2014 = Simon Pickl, Aaron Spettl, Simon Pröll, Stephan Elspaß, Werner König, Volker Schmidt. Linguistic distances in dialectometric intensity estimation. - Journal of Linguistic Geography 2 (1), 25-40. http://dx.doi. org/10.1017/jlg.2014.3.

Preston, Dennis R. 1999. Handbook of Perceptual Dialectology. 1. Amsterdam: John Benjamins Publishing Company. http://dx.doi.org/10.1075/z.hpd1.

Ross, Kristiina 2009. Eesti keel Henrikust Anton Thor Helleni. - Keel ja Kirjandus 8-9, 553-558.

Ross, Kristiina 2016. Eesti filoloogia sünd ja kirikulaulude tõlked. - Keel ja Kirjandus 8-9, 652-668.

Saareste, Andrus 1930. Wanradt-Kõlli katekismuse keelest. - Eesti Keel 4-5, 73-96.

Vedru, Gurly 2004. People on river landscapes. - Eesti Arheoloogiaajakiri 8 (2), 181-200.

Weiss, Hellmuth, Paul Johansen 1930. Bruchstücke eines niederdeutschestnischen Katechismus vom Jahre 1535. - Beiträge zur Kunde Estlands 15 (4). Reval, 95-133.

Young, Robert J. C. 2001. Postcolonialism. An Historical Introduction. New Jersey: John Wiley \& Sons.

\author{
Siim Antso \\ eesti ja üldkeeleteaduse instituut \\ Tartu Ülikool \\ Jakobi 2 \\ 51014 Tartu \\ siimants@gmail.com
}




\title{
Estonian dialect divisions in 16th to 18 th century texts
}

\author{
SIIM ANTSO
}

The article examins the formation of Estonian dialect divisions in the works of various authors of the 16th to 18th century. The selected texts were analyzed from a socio- and colonial linguistic viewpoint.

The origin of linguistics and dialectology in Estonia is foreign, as research was conducted by Baltic Germans. In the perspective of colonial linguistics, the effort to learn the local varieties and bring order to the languages was done not only to communicate better with the locals but also to impose cultural domination. Thus languages were modelled after the ruling class's mother tongue or Latin. The analysis also takes into account the effects of human and natural boundaries on dialect divisions, such as administrative borders, rivers, and forests.

The texts analyzed were for the most part of a linguistic nature, being grammars sometimes accompanied by dictionaries. However, some works of history where neighbouring languages were described from a dialect paradigm were also included. For the most part, larger historic administrative units were used to describe the dialect situation in 16th to 18th-century texts. On many occasions larger cities were used to mark a dialect area. In the case of Tartu and Tallinn, specific city language varieties were named to distinguish them from the surrounding dialect area. This kind of a distinction is expected, since the ongoing dispute between the Tartu and Tallinn written language had an immense effect on the whole dialect system.

The impact of natural obstacles was almost non-existent in the analyzed texts. It should be noted, however, that the current method only allowed for analysis of the texts themselves and the confirmed and plausible connections between them. Thus, a detailed inquiry with further material is yet to be conducted.

Keywords: Estonian, Estonian dialects, sociolinguistics, colonial linguistics, historical perceptual dialectology 